\title{
Comparison of Toxicity between Saxitoxin and Decarbamoyl Saxitoxin in the Mouse Bioassay for Paralytic Shellfish Poisoning Toxins
}

\author{
Hodaka SUZUKI ${ }^{1) *}$ and Kenji MACHII ${ }^{1)}$ \\ ${ }^{1)}$ Division of Biomedical Food Research, National Institute of Health Sciences, 1-18-1 Kamiyoga, Setagaya-ku, Tokyo 158-8501, Japan
}

(Received 25 April 2014/Accepted 15 July 2014/Published online in J-STAGE 10 September 2014)

ABSTRACT. The mouse bioassay (MBA) for paralytic shellfish poisoning (PSP) toxins has been used in the AOAC Official Method and the official Japanese method. In the AOAC Official Method, the saxitoxin (STX) standard provided by the U.S. Food and Drug Administration (FDA) is used, but no standard is used in the official Japanese method. The objective of this study was to compare the toxicity of decarbamoyl STX (dcSTX), one of the derivatives of STX and a candidate standard for the MBA for PSP toxins in Japan, to that of FDA STX in the MBA platform. In this study, the toxicity of dcSTX was $918.0 \pm 44.9$ mouse units/ $\mu$ mol, and the relative toxicity ratio of dcSTX to FDA STX based on moles was 0.478 .

KEY WORDS: comparative toxicity, decarbamoyl saxitoxin (dcSTX), mouse bioassay (MBA), saxitoxin (STX)

doi: 10.1292/jvms.14-0211; J. Vet. Med. Sci. 76(11): 1523-1525, 2014

The mouse bioassay (MBA) has been used as the official method for detecting paralytic shellfish poisoning (PSP) toxins in Japan since 1980 [7]. Briefly, the MBA for PSP toxins is performed as follows: Five or more male ddY mice, weighing 19-21 g (about 4 weeks old of age), are intraperitoneally (i.p.) injected with $1 \mathrm{~m} l$ of acid extract of a shellfish sample, and the time of death (the time from the end of the injection to the last gasp of breath) is observed. If the median death time is $<5 \mathrm{~min}$, the assay is repeated by diluting the extract so that the animals die 5-7 min after injection. The toxicity of the sample, expressed in mouse units (M.U.), is calculated from the median death time of a total of 5 or more mice by using Sommer's table (table concerning the relationship between death time and M.U. for PSP toxins). If mice, weighing $<19 \mathrm{~g}$ or $>21 \mathrm{~g}$, are included in the assay, weight correction using a correction table for the weight of the mice is needed [4, 6]. The official Japanese method basically conforms to AOAC Official Method 959.08 [1]. In AOAC Official Method 959.08, however, use of a saxitoxin (STX) standard provided by the U.S. Food and Drug Administration (FDA, Rockville, MD, U.S.A.), as a control is required, and toxicity is expressed in $\mu \mathrm{g}$ STX equivalent (STX eq), rather than M.U., calculated by using the results obtained with the STX standard, due to differences in such things as mouse strain, sex and conditions. (No details are provided regarding the requirements for mouse strain and sex in the AOAC Official Method.) In Japan, however, possession of STX is restricted by the Act on the Prohibition of Chemical Weapons and the Regulation of Specific Chemicals, so the

*Correspondence to: Suzuki, H., Division of Biomedical Food Research, National Institute of Health Sciences, 1-18-1 Kamiyoga, Setagaya-ku, Tokyo 158-8501, Japan. e-mail: hodaka@nihs.go.jp (C)2014 The Japanese Society of Veterinary Science

This is an open-access article distributed under the terms of the Creative Commons Attribution Non-Commercial No Derivatives (by-nc-nd) License $<$ http://creativecommons.org/licenses/by-nc-nd/3.0/>.
STX standard cannot be used in most facilities. Accordingly, in the official Japanese method, the strain and sex of the mice used are designated as an alternative to using the STX standard [4].

Decarbamoyl STX (dcSTX), which is one of the derivatives of STX and is not restricted by the Act on the Prohibition of Chemical Weapons and the Regulation of Specific Chemicals, is considered a candidate standard for the MBA for PSP toxins in Japan. In this study, we aimed to compare the toxicity between FDA STX and dcSTX using the MBA platform for PSP toxins.

Toxins: STX $(100 \mu \mathrm{g} / \mathrm{m} l$, lot No. 088, purity unknown, as STX $2 \mathrm{HCl}$ ) was kindly provided by the U.S. FDA. dcSTX $(2.55 \mathrm{nmol} / \mathrm{m} l$, purity $>95.0 \%$, as dcSTX diacetate salt) was kindly provided by the Hatano Research Institute, Food and Drug Safety Center (Hadano, Japan).

Animals: Specific pathogen-free male ddY mice at 4 weeks old of age were purchased from Japan SLC Inc. (Shizuoka, Japan) and kept in our animal facility for 1 day. The mice were kept at a room temperature of $20-26^{\circ} \mathrm{C}$ and relative humidity of 30-70\%, with a 12-hr light (09:00-21:00)12-hr dark (21:00-09:00) cycle. The mice were housed in plastic cages with wood chip bedding and were fed commercial pellets (CRF-1; Charles River Laboratories Japan Inc., Yokohama, Japan) and tap water ad libitum. All animal experiments were conducted with the approval of the Animal Care and Use Committee of the National Institute of Health Sciences, Japan.

Experimental designs: The MBA method was basically in accordance with AOAC Official Method 959.08 [1] and also the official Japanese method [4]. STX and dcSTX, adequately diluted in each experiment, were injected i.p. into 5 mice each, the time of death was measured, and the toxicity results (M.U.) were calculated by using Sommer's table and the correction table for the weight of the mice. In this study, weight correction was applied for more precise calculation, although all of the mice used weighed between $19 \mathrm{~g}$ and 
Table 1. Results of 3 experiments using the MBA for STX and dcSTX

\begin{tabular}{|c|c|c|c|c|c|c|c|c|c|c|c|}
\hline $\begin{array}{l}\text { Toxin } \\
\text { (dose) }\end{array}$ & $\begin{array}{l}\text { Mouse } \\
\text { No. }\end{array}$ & B.W. ${ }^{\text {a) }}$ & B.W.C.F. & $\begin{array}{l}\text { Lethal } \\
\text { time (sec) }\end{array}$ & M.U.c) & $\begin{array}{c}\text { Corrected } \\
\text { M.U. }\end{array}$ & $\begin{array}{l}\text { Median } \\
\text { M.U. }\end{array}$ & $\begin{array}{l}\text { Ave. } \pm \text { SD } \\
\text { of M.U. }\end{array}$ & $\begin{array}{c}\text { C.F. d) } \\
(\mu \text { g/M.U. })\end{array}$ & $\begin{array}{c}\text { Toxicity }{ }^{\mathrm{e}} \\
(\mu \mathrm{g} \text { STX eq })\end{array}$ & $\begin{array}{c}\text { Toxicity } \\
\text { ratio }\end{array}$ \\
\hline \multirow{5}{*}{$\begin{array}{l}\mathrm{STX} \cdot 2 \mathrm{HCl} \\
(0.370 \mu \mathrm{g} / \\
\text { mouse })\end{array}$} & 1 & 19.54 & 0.9862 & 326 & 1.764 & 1.740 & \multirow{5}{*}{1.852} & \multirow{5}{*}{$1.814 \pm 0.221$} & \multirow{5}{*}{0.1998} & \multirow{5}{*}{-} & \multirow{5}{*}{ - } \\
\hline & 2 & 20.34 & 1.0102 & 397 & 1.457 & 1.472 & & & & & \\
\hline & 3 & 19.96 & 0.9988 & 290 & 2.000 & 1.998 & & & & & \\
\hline & 4 & 19.86 & 0.9958 & 310 & 1.860 & 1.852 & & & & & \\
\hline & 5 & 20.27 & 1.0081 & 291 & 1.992 & 2.008 & & & & & \\
\hline \multirow{5}{*}{$\begin{array}{l}\text { dcSTX } \\
\text { diacetate salt } \\
(0.673 \mu \mathrm{g} / \\
\text { mouse })\end{array}$} & 1 & 19.72 & 0.9916 & 372 & 1.552 & 1.539 & \multirow{5}{*}{1.678} & \multirow{5}{*}{$1.610 \pm 0.159$} & \multirow{5}{*}{ - } & \multirow{5}{*}{0.3353} & \multirow{5}{*}{0.498} \\
\hline & 2 & 20.03 & 1.0009 & 430 & 1.364 & 1.365 & & & & & \\
\hline & 3 & 19.97 & 0.9991 & 342 & 1.680 & 1.678 & & & & & \\
\hline & 4 & 20.04 & 1.0012 & 335 & 1.715 & 1.717 & & & & & \\
\hline & 5 & 20.39 & 1.0117 & 332 & 1.730 & 1.750 & & & & & \\
\hline
\end{tabular}

\begin{tabular}{|c|c|c|c|c|c|c|c|c|c|c|c|}
\hline $\begin{array}{l}\text { Toxin } \\
\text { (dose) }\end{array}$ & $\begin{array}{c}\text { Mouse } \\
\text { No. }\end{array}$ & B.W. & B.W.C.F. ${ }^{b)}$ & $\begin{array}{c}\text { Lethal } \\
\text { time (sec) }\end{array}$ & M.U.c) & $\begin{array}{c}\text { Corrected } \\
\text { M.U. }\end{array}$ & $\begin{array}{c}\text { Median } \\
\text { M.U. }\end{array}$ & $\begin{array}{c}\text { Ave. } \pm \text { SD } \\
\text { of M.U. }\end{array}$ & $\begin{array}{c}\text { C.F. d) } \\
(\mu \text { g/M.U.) }\end{array}$ & 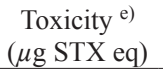 & $\begin{array}{c}\text { Toxicity } \\
\text { ratio }\end{array}$ \\
\hline \multirow{5}{*}{$\begin{array}{l}\mathrm{STX} \cdot 2 \mathrm{HCl} \\
(0.357 \mu \mathrm{g} / \\
\text { mouse })\end{array}$} & 1 & 19.78 & 0.9934 & 365 & 1.580 & 1.570 & \multirow{5}{*}{1.846} & $1.811 \pm 0.169$ & 0.1934 & - & - \\
\hline & 2 & 20.41 & 1.0123 & 299 & 1.928 & 1.952 & & & & & \\
\hline & 3 & 20.17 & 1.0051 & 295 & 1.960 & 1.970 & & & & & \\
\hline & 4 & 19.86 & 0.9958 & 311 & 1.854 & 1.846 & & & & & \\
\hline & 5 & 19.63 & 0.9889 & 331 & 1.735 & 1.716 & & & & & \\
\hline \multirow{5}{*}{$\begin{array}{l}\text { dcSTX } \\
\text { diacetate salt } \\
(0.673 \mu \mathrm{g} / \\
\text { mouse })\end{array}$} & 1 & 19.71 & 0.9913 & 363 & 1.588 & 1.574 & \multirow{5}{*}{1.695} & $1.714 \pm 0.274$ & \multirow[t]{5}{*}{-} & \multirow[t]{5}{*}{0.3278} & \multirow[t]{5}{*}{0.487} \\
\hline & 2 & 19.70 & 0.9910 & 283 & 2.056 & 2.037 & & & & & \\
\hline & 3 & 20.21 & 1.0063 & 439 & 1.339 & 1.348 & & & & & \\
\hline & 4 & 20.29 & 1.0087 & 342 & 1.680 & 1.695 & & & & & \\
\hline & 5 & 19.93 & 0.9979 & 300 & 1.920 & 1.916 & & & & & \\
\hline
\end{tabular}

\begin{tabular}{|c|c|c|c|c|c|c|c|c|c|c|c|}
\hline $\begin{array}{l}\text { Toxin } \\
\text { (dose) }\end{array}$ & $\begin{array}{c}\text { Mouse } \\
\text { No. }\end{array}$ & B.W. ${ }^{a)}$ & B.W.C.F. $\left.{ }^{b}\right)$ & $\begin{array}{l}\text { Lethal } \\
\text { time }(\mathrm{sec})\end{array}$ & M.U.c) & $\begin{array}{c}\text { Corrected } \\
\text { M.U. }\end{array}$ & $\begin{array}{l}\text { Median } \\
\text { M.U. }\end{array}$ & $\begin{array}{c}\text { Ave. } \pm \text { SD } \\
\text { of M.U. }\end{array}$ & $\begin{array}{c}\text { C.F. d) } \\
(\mu \text { g/M.U.) }\end{array}$ & $\begin{array}{c}\text { Toxicity e) } \\
(\mu \text { g STX eq) }\end{array}$ & $\begin{array}{c}\text { Toxicity } \\
\text { ratio }\end{array}$ \\
\hline \multirow{5}{*}{$\begin{array}{l}\mathrm{STX} \cdot 2 \mathrm{HCl} \\
(0.333 \mu \mathrm{g} / \\
\text { mouse })\end{array}$} & 1 & 20.14 & 1.0042 & 373 & 1.548 & 1.555 & \multirow{5}{*}{1.773} & $1.741 \pm 0.241$ & 0.1878 & - & - \\
\hline & 2 & 20.06 & 1.0018 & 307 & 1.878 & 1.881 & & & & & \\
\hline & 3 & 20.25 & 1.0075 & 402 & 1.440 & 1.451 & & & & & \\
\hline & 4 & 19.83 & 0.9949 & 283 & 2.056 & 2.046 & & & & & \\
\hline & 5 & 19.95 & 0.9985 & 324 & 1.776 & 1.773 & & & & & \\
\hline \multirow{5}{*}{$\begin{array}{l}\text { dcSTX } \\
\text { diacetate salt } \\
(0.640 \mu \mathrm{g} / \\
\text { mouse })\end{array}$} & 1 & 20.15 & 1.0045 & 344 & 1.670 & 1.678 & \multirow{5}{*}{1.474} & $1.493 \pm 0.121$ & - & \multirow[t]{5}{*}{0.2768} & \multirow[t]{5}{*}{0.433} \\
\hline & 2 & 19.96 & 0.9988 & 438 & 1.342 & 1.340 & & & & & \\
\hline & 3 & 20.10 & 1.0030 & 393 & 1.470 & 1.474 & & & & & \\
\hline & 4 & 19.83 & 0.9949 & 381 & 1.516 & 1.508 & & & & & \\
\hline & 5 & 20.15 & 1.0045 & 396 & 1.460 & 1.467 & & & & & \\
\hline
\end{tabular}

a) Body weight (g), b) Body weight correction factor by the correction table for the weight of the mice, c) Mouse unit by Sommer's table, d) Conversion factor, calculated as the amount of toxin injected divided by the median M.U., e) Toxicity was expressed as $\mu \mathrm{g}$ STX equivalent (STX eq), but it more precisely reflects $\mu \mathrm{g}$ STX $2 \mathrm{HCl}$ eq.

$21 \mathrm{~g}$. Then, the toxicity of dcSTX expressed in $\mu \mathrm{g}$ STX eq, was calculated by using the conversion factor (CF) for STX. The experiments were performed 3 times.

The results of the individual experiments are shown in Table 1, and statistical summaries are shown in Table 2. In each of 3 experiments, the toxicity of dcSTX diacetate salt was calculated using the $\mathrm{CF}$ for $\mathrm{STX}(\cdot 2 \mathrm{HCl})$, followed by the AOAC Official Method. It was calculated that $0.640-$ $0.673 \mu \mathrm{g}$ of dcSTX diacetate salt represented $0.277-0.335 \mu \mathrm{g}$ STX eq (officially called STX eq in the AOAC method but should be called STX $2 \mathrm{HCl}$ eq, as the FDA STX standard is not STX but is STX $2 \mathrm{HCl}$ ), and the toxicity ratio of dcSTX diacetate salt to $\mathrm{STX} \cdot 2 \mathrm{HCl}$ based on weight was $0.473 \pm$ 0.035 (0.433-0.498) (Tables 1 and 2). The molecular weights of STX $2 \mathrm{HCl}$, STX, dcSTX diacetate salt and dcSTX are $372.21,299.29,376.37$ and 256.26, respectively, and it was calculated that the toxicity ratio of dcSTX to STX based on weight was $0.559 \pm 0.042$ and that that of dcSTX to STX based on moles was $0.478 \pm 0.036$ (Table 2).

Previously, Oshima [3] reported that the toxicity values 
Table 2. Comparative toxicity of dcSTX to STX calculated by the median values of the 3 experiments

\begin{tabular}{|c|c|c|c|c|c|}
\hline & Toxins & $\begin{array}{c}\text { Toxicity } \\
\text { (M.U./ } / \mu \mathrm{mol})\end{array}$ & $\begin{array}{c}\text { Toxicity ratio of dcSTX } \\
\text { diacetate salt to STX } 2 \mathrm{HCl} \\
\text { (weight based) }\end{array}$ & $\begin{array}{l}\text { Toxicity ratio of } \\
\text { dcSTX to STX } \\
\text { (weight based) }\end{array}$ & $\begin{array}{c}\text { Toxicity ratio of } \\
\text { dcSTX to STX } \\
\text { (mole based) }\end{array}$ \\
\hline \multirow[t]{2}{*}{ 1st Exp. } & STX $^{\text {a) }}$ & 1863.0 & - & - & - \\
\hline & $\mathrm{dcSTX}^{\mathrm{b})}$ & 939.0 & 0.498 & 0.589 & 0.504 \\
\hline \multirow[t]{2}{*}{ 2nd Exp. } & STX & 1924.6 & - & - & - \\
\hline & dcSTX & 948.5 & 0.487 & 0.576 & 0.493 \\
\hline \multirow[t]{2}{*}{ 3rd Exp. } & STX & 1981.7 & - & - & - \\
\hline & dcSTX & 866.5 & 0.433 & 0.511 & 0.437 \\
\hline \multirow[t]{2}{*}{ Ave. \pm SD } & STX & $1,923.1 \pm 59.4$ & - & - & - \\
\hline & dcSTX & $918.0 \pm 44.9$ & $0.473 \pm 0.035$ & $0.559 \pm 0.042$ & $0.478 \pm 0.036$ \\
\hline
\end{tabular}

a) The STX standard was provided by the FDA, but more precisely, it was STX·2HCl., b) As dcSTX diacetate salt.

of STX and dcSTX were 2,483 and 1,274 M.U./ $\mu$ mol and that the relative toxicity ratio of dcSTX to STX was 0.513 . Recently, Munday et al. [2] reported that the toxicity values

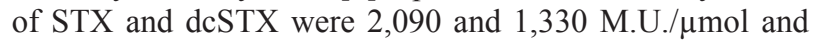
that the relative toxicity ratio of dcSTX to STX was 0.636 . In this study, the toxicity values of FDA STX and dcSTX were $1,923.1 \pm 59.4$ and $918.0 \pm 44.9$ M.U./ $\mu$ mol, and the relative toxicity ratio of dcSTX to FDA STX was 0.478 . In our present results, the relative toxicity ratio of dcSTX to STX was quite similar to that in Oshima's report, although the toxicity values of dcSTX and STX were slightly lower than those in the other 2 studies.

As mentioned above, there is no standard used in the official Japanese method, and dcSTX is considered as a candidate standard for the MBA for PSP toxins in Japan [5]. Use of dcSTX as a standard would help minimize individual differences among assays. The relative toxicity ratios of dcSTX to STX were not so different among the studies ( 0.478 in this study, 0.513 in Oshima's report [3] and 0.636 in Munday's report [2], based on moles); however, an interlaboratory collaborative study is needed to determine the official conversion factor of the dcSTX standard to the STX $(\cdot 2 \mathrm{HCl})$ standard provided by the FDA in the future.

ACKNOWLEDGMENTS. We are very grateful to Dr. Sherwood Hall, Food and Drug Administration, and to Dr. Tatsuya Suzuki and Dr. Takuho Watanabe, Hatano Research Institute, Food and Drug Safety Center, for their gifts of toxins. This study was supported by Grant-in-Aid for Scientific Research (C) (KAKENHI) Grant No. 25450437 from the Japan Society for the Promotion of Science (JSPS).

\section{REFERENCES}

1. AOAC INTERNATIONAL. 2005. Chapter 49. AOAC Official Method 959.08, Paralytic Shellfish Poison, Biological Method, First Action 1959, Final Action. pp. 79-81. In: Official Methods of Analysis of AOAC INTERNATIONAL, 18th ed. (AOAC INTERNATIONAL ed.), AOAC INTERNATIONAL, Gaithersburg.

2. Munday, R., Thomas, K., Gibbs, R., Murphy, C. and Quilliam, M. A. 2013. Acute toxicities of saxitoxin, neosaxitoxin, decarbamoyl saxitoxin and gonyautoxins $1 \& 4$ and $2 \& 3$ to mice by various routes of administration. Toxicon 76: 77-83. [Medline] [CrossRef]

3. Oshima, Y. 1995. Post-Column derivatization HPLC methods for Paralytic Shellfish Poisons. pp. 81-94. In: Manual in Harmful Marine Microalgae (Hallegraeff, G. M., Anderson, D. M. and Cembella, A. D. eds.), UNESCO Publishing, Paris.

4. Oshima, Y. 2005. Chapter 7. Shizendoku (Natural Toxins) 3. Mahisei Kaidoku (Kouteihou) (Paralytic Shellfish Poisoning Toxins (Official Method)). pp. 673-680. In: Syokuhin Eisei Kensa Shishin (Standard Methods of Analysis in Food Safety Regulation) (Kousei Roudou Sho (Ministry of Health, Labour and Welfare) ed.), Japan Food Hygiene Association, Tokyo (in Japanese).

5. Oshima, Y. 2009. Nimaigai no doku (Shellfish toxin) (2): Mahisei kaidoku (Paralytic shellfish poisoning toxins). Food Sanit. Res. 59: 21-27 (in Japanese).

6. Suzuki, H. and Machii, K. 2013. Effects of injection speed of test samples on the mouse bioassay for paralytic shellfish poisoning toxins. Ital. J. Food Saf. 2: 70-73.

7. Veterinary Sanitation Division Director-General. 1980. Notification No. 30 of Veterinary Sanitation Division, from the Veterinary Sanitation Division Director-General, Veterinary Sanitation Division, Environmental Health Bureau, Ministry of Health, Labour and Welfare (in Japanese). 